\title{
DEVELOPMENT OF COMMUNITY HEALTH SERVICES FOR THE ARAB VILLAGE POPULATION IN ISRAEL
}

\author{
REBECCA ADAMS STOCKLER \\ R.N., Ed.D. \\ Department of Nursing, Sackler School of Medicine, Tel-Aviv University
}

\section{OPSOMMING}

Die ontwikkeling van gemeenskapsgesondheidsdienste vir die Arabiese plattelandse bevolking in Israel sedert 1948 word bespreek. Daar word veral gekyk na die ervarings van die verpleegkundiges, geneeshere en sanitêre werkers in die veld. Hulle het nie net met gesondheidsprobleme te kampe gehad nie, maar ook met talle kulturele struikelblokke in die lewering van voorkomende, genesende en rehabilitasie dienste.

\section{THE SITUATION IN 1948}

With the proclamation of the State of Israel in 1948 the war began between Israel and her neighbours and the health services for the entire population were at a minimum. Among the Arab population where such services did exist, the personnel - doctors, nurses, teachers - fled; those in Jerusalem went to Jordan and in the North, Haifa was the point of departure for Lebanon and other countries (Mizrahi 1981, Ron 1981). Israel was engulfed at the same time by mass immigration from Asian and African countries, and by survivors of the European Holocaust. The state of

Rebecca Adams Stockler has had many years of experience in community health nursing both in the United States and in Israel. She has been chairperson of the Department of Nursing in the Sackler School of Medicine, Tel Aviv University and is at present teaching in the same department. health of these people was poor to say the least. Diseases which had almost been eliminated in the area were found among the immigrants - trachoma, blindness, bilharzia, tuberculosis, malnutrition and mental illness (Tulchinsky 1979). These people had to be brought in and cared for immediately, a task which could have overwhelmed many a wealthier and more settled government

When the new Ministry of Health finally turned to administration and planning it found that although the structure of the Mandate public health services was a good framework, it was inadequate for the needs of the state. Qualified administrative staff as well as field personnel were also grossly insufficient in numbers. There was no division of services to deal with tuberculosis, child health, mental health and venereal disease. Sanitary engineers had no power or duty except to recommended or reject plans submitted by the local authority. Although there were many Jewish physicians, few of them had training or experience in public health or in administration

There were public health nurses among the Jewish population but they were too few for the whole country. Physicians, nurses and administrative staff were drawn from existing Jewish institutions. By dint of improvisation, trial and error and advice from the United States of America Operations Mission (USOM 1956) regulations were laid down and structures formed (Tulchinsky 1979, Ministry of Health 1948), You must imagine the difficulties, wrote Dr Katznelson, the Director-General of the Ministry, no qualified staff, building difficulties, and almost no supplies. (Ministry of Health 1948). For administrative purposes the State had been divided into regions and in the Health Ministry each region was responsible for a group of local health districts. Nazareth became the regional center for the North, with responsibility for Acre, Safed, Kinneret and Afula sub-districts; Haifa was the seat for Haifa and Hadera sub-districts; Tel Aviv was the regional department for the city of Tel Aviv; Ramleh was responsible for the city of Ramleh, Netanya, Petach Tikvah and Rehovoth. Jerusalem was the regional department for Jerusalem and the corridor settlements and the Southern region was administered by Beersheba, which included Beersheba, Ashkelon and the Negev (Ministry of Health 1953). 
Early plans included a separate division for Arab services, but these were cancelled in 1953. Dr. Btesh wrote that as there was no difference in care for the total population, there would not be a special department of health for the minorities; all health care would be under the aegis of the Ministry (Ministry of Health 1953).

Services in the urban areas were available to all sectors of the population - preventive services from the Ministry, curative from Kupat Holim (Sick Fund of General Federation of Labour) for its members and from private doctors.

In 1948 some curative services existed in Abu Gosh, Faradis and Gush Halav (Arab towns) although only four Arab doctors, a number of nurses and auxilliary workers were available in that year (Ministry of Health 1948). These doctors and nurses made periodic visits to various clinics and were able to give only minimal services. By $1953 \mathrm{cu}$ rative services under the supervision of the Ministry of Health had become available in Shfar Am, Kfar Yassif, Usfia, Tamra and Baka El Garbieh. Two clinics existed for Beduin in the Beersheba area, and immunisations were given in the local health department. The nomadic Beduin were served by a physician and nurse travelling by jeep to the various encampments (Ministry of Health 1953). Health centers were planned for Tira. whose center was inaugurated 1956 , and for Baka El Garbieh, which opened in 1958 (Hadera Health Department 1976, Ministry of Health 1953, Lifshitz 1981, Brachot 1981).

Legislation, planning, administration and budgets were factors in giving good health care but perhaps more important were the health workers without whom the plans could not have been implemented.

\section{NURSES}

The first functions Shoshana Oser carried out for the Acre Health Department in 1955 were epidemiologic investigations and wide scale immunisations. Everything was a problem - transport, materials and language. In the early years one truck served the nurse, the sanitarians and anti-malaria workers and each one felt he should have first choice, while the driver made the decisions according to his ideas (Oser 1981).

\section{Epidemiological investigations}

Dyphtheria, typhoid and polio were the main diseases and there were trachoma and ringworm. The population did not always take kindly to the investigations and could not see the reasons for laboratory examinations. Shuval (1955) found that uneducated villagers believed dysentery were caused by a cold, no specific answers were given for typhoid transmission, malaria was caused by standing water or from drinking dirty water, tuberculosis by the bite of a fly or mosquito or uncovered garbage. So it is small wonder that during and after an outbreak of typhoid fever Shfar Am residents gave stool samples that were not their own.

In another outbreak in Emek Bet Netufa where the majority of sick were children, the Israeli army sent a helicopter to hospitalise them but to no avail - the Mukhtar (head man) objected. A nurse and sanitarian were sent with medications to visit daily which meant a daily trek by foot for six kilometers because in winter the road was impassable

Even where there was a road the driver might refuse to enter a village. One such driver decided he had no fuel and when it was pointed out that he had, he pushed a rag into the tank. Eventually came the tale - the driver's family had a feud with one in Kfar Manda and he was afraid of being attacked. The nurse and the sanitarian walked. Epidemiological investigations for venereal disease were complicated. No male would consider giving the names of his contacts and when a female contact was found, the Arab speaking sanitarian said he could not enter her house since the neighbours would gossip about him.

\section{Immunisation}

Along with the frustrating investigations immunisations were given. Dyptheria toxoid was available in sufficient quantities since 1951, tetanus and dyphtheria in 1955, triplex in 1957, poliomyelitis vaccine in 1957 and measles vaccine in 1966. Smallpox and typhoid vaccines had been available long before the establishment of the state (Grushka 1968).

Where there were no maternal and child health centres, immunisation projects entailed a great deal of preparation and sometimes they ended unsuccessfully. When the material was available a time table was set up and the villages had to be notified. In Acre the Arabic speaking driver knew when the villagers came to the market and he was sent to inform the men sitting in the coffee houses. He knew when planting and harvesting took place and everyone would be in the fields, which families were feuding so the school should be used as a neutral meeting place, and when holidays and weddings took place.

Of course, the truck could need repairs, the roads, such as they were, might be impassable and the thermoses broke easily. Oser showed her improvising skills by preparing sawdust in unbleached muslin made into pockets, freezing small coffee cans with water and placing these and the immunisation material within the shell of the thermos. Syringes were arranged in the same material, needles packed in cardboard containers and all sterilised in the Acre Mental Hospital's autoclave. Weighed down with this paraphernalia as well as a primus and kettle, the nurse arrived in the village where she immediately boiled water for resterilisation since the number of syringes and needles was limited. A teacher or driver registered names since the first Jewish nurses knew little Hebrew and less Arabic (Oser 1981). Not infrequently there were misunderstandings due to language and the nurse who thought she was asking women if they were pregnant during smallpox vaccination, was actually asking them if they were donkeys. The error had to be rectified with much explanation.

The public was not always keen on immunisation nor was the local council always helpful. Although the nurse was promised that the town crier in Shfar Am would call the mothers for a certain day this was not done. Nurses and social workers did not have enough standing among the male leadership so that the latter felt no obligation to carry out their promise. The spectacle of the nurse driving a car and the social worker using a loudspeaker to call the women in Arabic, however, was interesting enough to bring the women out en masse with their infants.

Druze were fatalistic and since everything was in Allah's hands, why immunise. Physicians and 
nurses finally convinced the villagers that although Allah was indeed most important, even soldiers carried guns into battle and this seemed to convince families to immunise their children (Frank Blum 1981).

In Tira the mukhtar explained why no child appeared for typhoid immunisations. The villagers were convinced the Jews' injections would sterilise the boys and the girls would become barren. Not only that, but blood taken from the children would be used for Israeli scldiers. Health personnel overcame these difficulties by involving the Arab workers of all levels in the centre so that they could convince the population of the honest intentions of the health department (Lifshitz 1981, Feldman 1981).

\section{Other problems}

When Arabic speaking nurses began to work, they told their supervisor that after a day's work they were not ready to climb the hill from the village to the road where the transportation awaited them. Since Shoshana Oser's creed was that she would not demand from others what she herself could not do, she went to the village with the nurses. Downhill in the morning was pleasant but returning in the heat of the day would be difficult. Seeing this Oser asked for a donkey for the trip uphill. Finally an aged donkey who could barely walk was found and Oser tried to mount him. A woman does not ride a donkey, she was told, so it was only after the village was out of sight that the ride began. With the owner pulling and a boy pushing the donkey, the group arrived at the road where the truck waited. The fee was lowered from the astronomic sum of three lira to two but the Ministry of Health had no funds for donkey rides (Oser 1981).

Case finding and preventive care for malaria were introduced in addition to spraying of mosquito breeding areas. A team of sanitarian, nurse, antimalaria worker and clerk would arrange a day when the entire population would have blood smears taken. Treatment was less effective since people forgot to take their medications.

Tuberculosis case finding, treatment, follow-up of the whole population and BCG immunisation for newborns as a routine and for school children when necessary, the latter begun in 1955, met with singular success. The work was done by a special team of the $\mathrm{Tu}$ berculosis League and involved much explanation in Arabic and making home visits. Hospital beds were made available in Nazareth for the nothern district and in Beer Yakov hospital for the south. These beds have since been closed because of lack of patients and the cases under care receive ambulatory treatment (Torok 1981).

Additional programs existed before maternal and child health stations and clinics were set up and these included case finding and treatment for trachoma and ringworm. Sometimes physicians came to examine villagers for trachoma and ringworm in children and sometimes nurses were taught to do the screening. Treatment for trachoma was given by teachers and in the 1960 's physicians found that the disease was non-existent even in areas where no treatment had been instituted. Apparently improved personal hygiene, water supplies and better environmental sanitation had done its work

Ringworm of the scalp, a disease of more social implication than of health importance, was treated in the 1950 's with X-ray epilation followed by application of iodine to the scalp. Fortunately, Grisofulvin was introduced soon afterwards (Grushka 1968). Here too preparation was of utmost importance. In Tira and Taibe everyone was notified by door to door visiting of the coming examinations, school children and contacts were examined and treatment given by the teachers (Gordon 1981). Various studies with the drug proved that one large dose cured the disease and this is how it was treated (Lifshitz 1981).

Almost every child in Tira had hookworm and thousands of infected children were treated with alcopar and as a preventive measure were taught to wear shoes. It should be noted that the improved economic situation contributed to the willingness to buy and wear shoes (Lifshitz 1981).

Many tales can be told of the nurses' experiences during the period when few services existed and only immunisations could be given. So much had to be done for the dystrophic babies, for schoolchildren, and hygiene in general, but time was limited, the driver would not wait and public transportation was not developed.

When Shoshana Oser and the sanitarian Joseph Barhum decided to remain in a remote western $\mathrm{Gal}$ ilee village to complete typhoid immunisations for schoolchildren, they stayed the night in the home of a Christian teacher. The director of nursing in the northern district raised a hue and cry when she heard that one of her nurses did not return home and made a special trip the next day to reassure herself that all was well (Oser 1981). The Arabs thought the Jews were taking their children's blood and the Jews feared for the welfare of the staff.

Pleasure and satisfaction were also felt by the nurses. Such was a visit with the sanitarian and antimalaria worker to Wadi Salameh. a Beduin encampment which no approach roads, truly a Valley of Peace as its Arabic name indicates. The women rejoiced to see visitors and the nurse was the Englishwoman because they had never heard of an American. Perfect fall weather, working in the open, and the friendliness of the people were sufficient reward for the long trek to the highway.

\section{Permanent services}

Slowly, organised permanent services were set up and some nurses lived in the villages in which they worked. The situation presented its problems. Practical nurses were expected to give preventive as well as curative care and of course the population did not accept the limitations of permissible practice and demanded medications, especially penicillin injections. Family prestige also played a role in the nurse's life. When one family called the nurse at night, another family was certain to call her the following evening.

The nurses from the towns were not always aware of the behaviours of other ethnic groups. A Christian midwife came to Acre Health Department one day in great distress. She had shaken hands with a Druze elder and this was strictly forbidden although the man knew this and the nurse did not. Explanations were given, a reconciliation was made and the nurse learned her lesson.

Since the physician visited only once or twice a week, making diagnoses and prescribing medications were forced on the nurse. To help 
her, standing orders for common ailments were written (Frank Blum 1981). On a visit to a village clinic, the supervisor asked the young practical nurse how she treated various conditions, how she gave immunisations and instructed mothers in infant and child care. The nurse answered everything correctly always adding, Hakima told me to do it so. An astounding answer, but who was the wise woman who gave such good instructions? It appeared that the word hakima was used for the woman doctor.

Nevertheless, practical nurses did not always know the answers, and the child who fell from the roof of his house was sent home and lost consciousness before being sent to hospital. Even the graduate nurse had qualms when called to a home where the family said the child had smallpox. The only variola the nurse had seen was in a textbook and it took courage to make a diagnosis of chicken pox.

As one looks back, it is surprising that so few accidents and mistakes occurred and that the nurses were accepted. A refugee nurse-midwife from Egypt went to live under very difficult circumstances in a mountainous Druze village. It is to her credit that she could practice as she saw fit and still win the respect and affection of the villagers. Not always, however, was the Jewish staff admired; when the Arabic speaking nurse in Tira asked a mother to bring her son in for examination and triplex booster, the mother was heard to say: Come my son, you will grow up strong and will be able to kill the Jews (Feldman 1981).

\section{Mother and child care}

Preventive care was foreign to the population and much persuasion had to be done by all personnel to convince families to bring infants and toddlers, let alone pregnant women, to the station. Folk remedies were considered better.

For measles there was a red cloth on the head and forty days in a dark room; abscesses were opened with a hot iron; the newborn's cord was covered with earth or coffee grounds, as occasionally were the smallpox vaccinations. Cradlecap strenthened the baby and mothers politely refused to follow the nurse's instructions to cleanse the head. When a child died his death was not always reported but his name transferred to a new child so that not infrequently a newborn appeared before the nurse as aged three or four years (Gordon 1981). To confound the staff still further the women gave different names for themselves on various visits; they carried their father's name, clan name and occasionally added the husband's name.

Medications were made from plants known to the old women and wise men. The latter was consulted by a mother before her child with suspected haemophilia was hospitalised although his older brother had died from a haemorrhage. The second child was finally diagnosed as pseudohaemophilia and the credit went to the wise man.

Much time was involved in introducing changes; not only the population had to be convinced, some of the nurses also believed more in the efficacy of home remedies than in preventive care. Gradually the mothers learned that there was something to be done if a baby was not thriving - solids could be added before the infant became a toddler. Infant diarrhoeas were to be treated immediately; dystrophic infants could even be hospitalised without waiting for the father's permission.

Eventually health centres and stations became meeting places, and for these visits the child and mother were dressed in all their finery. The paediatrician's visit brought out the entire infant population and it was a good opportunity to examine infants and immunise them at the same time. Mothers waited patiently and when babies cried, the breast was quick succour.

Some nurses began to add use of slides and placards on hygiene to the routine nurses' work and in cooperation with social workers held group meetings with mothers. One such attempt at teaching women the use of bottled sterilised milk during calving season, when there was no fresh milk, was almost disastrous. It seems the women were completely disinterested in dairy dishes. They wanted to learn contraceptive measures, but their husbands were not yet ready for such an innovation. Several years were to pass before family planning clinics became part of the health services.

Instituting prenatal care was a slow process, and in the beginning few saw its value. Eventually, even if understanding the need was not widespread the prenatal card with patient findings completed by the nurse was necessary for hospital admission and visits became the norm. Certainly the younger more educated women came to appreciate preventive services during pregnancy

During the early years of the state few Arab women delivered in hospital. Rosenfeld (1956) noted that in Taibe some 90 percent had their children at home, attended by midwives of whom a few were registered but the others unqualified. This was typical of the state of affairs in the villages. A small percentage of mothers went to hospital for delivery but Rosenfeld believed that this was done to increase status rather than due to a belief in medical facilities.

The midwife is now paid in cash (formerly only in gifts) generally around five pounds, but not a fixed amount and also with presents such as flour and soap. The amount of cash is increased when the newborn is a boy and the midwife's chances of getting an additional good news gift is like-wise increased when the child is a boy. The midwife not only helps during labor, but also prepares for the child, cuts the umbilical cord, bathes the child (with salt and water), swaddles it initially and disposes of the afterbirth. (Rosenfeld 1956)

\section{Traditional practitioners}

Midwives were expected to be older women who had passed the menopause (Rosenfeld 1956). It was because of these dayas that serious health problems arose. Dr. Lifshitz (1981) told that the total age of three of these women was 225 years and their practices were almost as old. A physician in Tira was finally called to a woman haemorrhaging, not having expelled the placenta. She was saved by a transfusion given to her on the floor of her home (Lifshitz 1981). To combat the home deliveries, women were invited to deliver in the health centre with the dayas present (as observers); not only that, the health centre paid the daya and gradually home deliveries ceased (Feldman 1981).

Other medical practices were carried out by village women such as removing the uvula, considered a preventive measure against many diseases. In spite of accidents (one practitioner cut a child's palate and caused haemorrhage) people continued to receive these ministrations. Wise men treated fractures of 
the patella with a splint. Some of the traditional healers had to be warned to stop, others, in cases of dire results, were taken to court. Whether the population continued to visit the former is open to question (Dr. Ben Assa, 1974, believed they did) but they did begin to visit the clinics and stations and to deliver in the health centre (Lifshitz 1981).

Health workers soon saw that intensive teaching and follow-up were necessary if they were to control the dysenteries and subsequent dehydration among young children. Tira opened a day hospital where infants and toddlers were treated and mothers instructed; and in the afternoon the nurse made home visits to see if instructions were carried out (Lifshitz 1981). In Western Galilee weekly visits were made by a nurse to the area hospital to learn of all the children's conditions and to prepare for home care through follow up by the village nurse (Oser 1981).

\section{Rehabilitation}

Rehabilitation was not considered necessary, particularly for girls, possibly because of the fatalistic approach to life, illness and death. and status of women. However, the villagers eventually learned the value of rehabilitation and co-operated if funding was not involved.

In the early fifties, when poliomyelitis outbreaks occured, children were hospitalised but the long periods away from home brought social problems. The child forgot Arabic, wanted Jewish food and felt a stranger upon coming home. To help solve the problem, Acre Health Department, with the financial aid of the philanthropist $\mathrm{Mr}$. Wim van Leer, opened a rehabilitation clinic for children suffering from the aftermaths of polio. The village children came to this clinic to receive physiotherapy during the day and to return to their homes in the afternoon. This does not mean that there were no problems of transportation and obtaining funds for braces, but successful care was given (Oser 1981).

When curative clinics were opened in the rural areas crippled children and young adults, who had never received care, were found. The nurse and doctor discovered one such young woman, who had crawled on hands and feet for many years; her arms and legs were so fragile everyone feared fractures; her hair hung down over her face and her language was limited. When this poor creature was hospitalised, taught to walk with braces, to read and write, she was found to have more than average intelligence. Many resources were needed to prepare for her discharge and needless to say the young woman suffered from her new awareness and her family's lack of interest. Such extreme examples were not seen later on and people began to ask for care rather than wait for the public health nurse to find the needy.

\section{The aged}

Aged and aged ill were looked after physically and socially by their families even when the physical conditions did not lend themselves to ideal care. Dr. Torok (1981) noted changes in the 1970's even among the Beduin. In their new found freedom and financial independence they had been leaving the family compound and the aged to their own devices.

\section{School health care}

School health services lagged behind and there were several reasons for this. Emphasis in health care was primarily on lowering the infant mortality and morbidity rates of the entire population and nurses who knew the language had little formal preparation in health education. The maximum one could expect was the supervision of personal hygiene, immunisations and helping the physician carry out physical examinations when the latter was available. Vision testing was done but audiometry only where the school had electricity and in the early years of statehood this was almost non-existent. The buildings were unsuitable for teaching and for giving health care as well. When the trachoma expert came to an outlying school, she examined eyes and the nurse immunised, both working in the open air.

Of course, the primus stove went out with every puff of wind and the water had to be filtered and boiled. The physician who had however seen much worse during the war years in Europe tried to calm the despairing nurse.

There were improvements in the children's health. Communicable diseases were eradicated; contact with the Jewish population taught the parents new health habits; teachers transmitted their ideas to children; and introduction of water and electricity helped to raise the standards of hygiene. Thus preventive services, along with rising standards of living, brought positive change.

\section{Physicians}

Shuval in her study of Taibe (1955) came to the conclusion that the population believed in traditional care for mental illness but the western prepared physician was suitable for organic ailments. The educated had a greater degree of confidence in western medicine than the uneducated, but among the uneducated, the women believed more in the physician's care than the men.

Interesting are the variables involved in being a member of the upper class: running water in the house, indoor bath or shower, indoor toilet, ice box, and number of persons per room. The author concluded that teaching on various levels would help change health habits of the population. It is unknown whether western oriented physicians used many principles of health education, more likely they used the learned approach of their origins. Time, for example, was of utmost importance for one physician but the clients, having no clocks, came when they had completed their daily chores. It was the doctor who finally acquiesced.

\section{Difficult circumstances}

When Dr. Frank Blum began to work for the Ministry, the conditions were overwhelmingly bad clinics were cold, without windows or toilets; there were almost no medications and very few back up services such as a laboratory and diagnostic clinics existed. The health of the villagers was poor and the socio-economic situation bad. Shaab village was a prime example of extreme poverty and illness: there was no road and water had to be fetched from a well four kilometres away because the village well had dried up. Much of the able population had left with only a small group and some Beduin remaining. Tuberculosis was rife, there was much anaemia among the women, rheumatic fever rates were high, children suffered from marasmus and skin diseases as well as the ever present diarrhoeas.

Visits to the doctor in Shaab as well as in other villages were frequent but people could not give any history of complaints. When, added 
to this, the interpreter lost something in translation the physician had to search hard. No power of $o b$ servation, said Dr. Frank Blum. A child of four years was brought into the clinic with a edematous face. Suspecting glomerulonephritis she asked whether anyone had seen the child's urine and the answer was that it had been seen and was allright. The urine turned out to be red but to the clients there was no difference. Everyone demanded injections since they were painful, went directly into the blood, and were similar to the wise man's treatment (Frank Blum 1981). Some physicians were lavish with injections to please the patients, others tried to convince them of other ways but it took time.

Cold was a frequent diagnosis in deaths of newborns. Studies finally pinpointed the group at risk - infants under three kilos of weight who developed bleeding into the lungs. The children who died were those in unheated homes and had insufficient care. With follow up and instructions by the nurse regarding heating and general care, the mortality rates were reduced by a half to a third. (Frank Blum 1981)

\section{POOR COMPLIANCE}

Adherence to medical advice was not considered necessary in many cases. Continuity in taking medications and special diets such as a low salt one were not understood and not followed. For pregnancy some treatments were complied with; a young woman who had aborted several times because of diabetes learned to inject herself and her husband was willing to test her urine (Frank Blum 1981). Patients found they could keep the insulin cold by placing it in the earth (Torok 1981).

Family planning was taboo until the 1970's when a Moslem physician came to Acre Health Department. From him the idea was accepted the population was ready but needed a catalyst to make the practice of birth control legitimate. The teaching of methods began quietly as part of maternal and child health care, information spread and today clinics are well frequented. Acceptance of the physicians who earned the trust of the villagers was complete. When the mukhtar of Sachnin walked into the clinic unannounced while Dr. Frank Blum was examining a female patient, the woman physician politely but firmly showed him out. Such behaviour was unheard of and a sanitarian begged the doctor to let him arrange a sulha (peace). That is not necessary, said she and several months later, as she boarded the bus in the village to reach her car at the main road, the mukhtar was there. As both descended he took her bag and helped her into the car, all seen and marvelled at by passersby, the ultimate in sulhas (Frank Blum 1981).

Other physicians in that era had their experiences to relate in their practice among the Beduin in the south. Dr. Ben Assa and his wife, a pediatrician, came to Beersheba in 1955. He learned Arabic, travelled by jeep, made visits to the tents, understood his patients and had the love and devotion of the tribes.

The Beduin believes that the power and skills of the physician are really in the hands of Allah. Health comes from Allah, it is the saying of the Beduin. If the heavens decree that a man shall die nothing will help and the Beduin will never blame the physician (Ben Assa 1974).

Allah was also believed to be present during conception and without him pregnancy could not take place (Rosenfeld 1956). Beduin look upon the doctor as an agent or tool of Allah. Allah can only improve the physician's status but not his abilities (Ben Assa 1974). Dr. Ben Assa appreciated their philosophy, knew their health and social behaviours. If a Beduin told the doctor that he was the wisest man in the Negev, that he was the director of all the physicians, that the patient would visit no other physician, and that when cured he and his family would visit the doctor at home and the talk took more than five minutes, it was certain no payment would be made. At this time it was advisable to cut the conversation short and make a rapid diagnosis. Agile questioning brought out that the patient had already been to several doctors and healers and had received a number of treatments and medications.

Beduin in Beersheba had access to Kupat Holim clinics, the Ministry of Health clinics, outpatient clinics of the regional hospital, and at least three private doctors. Everyone ordered X-rays, laboratory tests and dispensed kilograms of medications. Fortunately for the Beduin they did not use the medications so danger in that regard was minimal. Dr. Ben Assa hoped that eventually each inhabitant would receive a card with the owner's picture, males only, since women were not per- mitted to be photographed, and each doctor's visit and prescriptions would be noted.

\section{Health beliefs and practices}

Diseases among the Beduin were the same as in the rest of the population: tuberculosis, dysenteries, measles, malnourishment and with the stresses of modern life even myocardial infarcts. Night blindness was mentioned as being frequent and some severe diarrhoeas among infants were thought to be due to lack of folic acid.

Symptoms and causality that did not appear in textbooks were pain in the entire body and children's illnesses due to the falling of the uvula. Other complaints were bites from ticks, spiders, camels and leeches in the throat. Women sometimes complained that their uterus was moving about in the abdomen, a diagnosis made by the old women in the tribe. Another mysterious female malady was the closure of the uterus forty days after delivery because a menstruating woman entered the tent. Treatment was most interesting - bathing in the blood of the suspected woman, and if that was not possible, then goat's blood was a satisfactory substitute. Sudden impotence of young males was brought about by a woman hiding charms in the tent. The best treatment for the latter was a visit to the Darwish, the folk healer who made charms from the writings of the Koran.

Approaches to care changed Whereas the Beduin women would not undress completely, in later years they agreed to gynaecological examinations if the doctor asked for their permission.

Now the young Beduin male comes to the physician with the same complaints as his Jewish neighbor (Ben Assa 1974). Rosenfeld (1956) wrote that in Taibe, where similar folk practices took place, most of the people have lost real contact with their philosophy towards disease. It is the older generation that still carries with it the seeds of their conceptual beliefs and also with it their treatments for such diseases.

There are sections in the Middle East such as the Sinai Desert where the Beduin population can still be seen as their brothers in the Negev appeared as little as twenty years ago. A young physician, Dr Kaminsky, has related his experiences as practitioner to these people with admiration, respect and love. It is easy and pleasant to work with 
them, they are thankful and polite, but continuity of care and visits for follow-up are unknown to them. If the doctor had not looked for a bleeding post partum woman and sent her to hospital, she would have died in the tent without asking for medical care. Dayas and elderly women are the decision makers in matters and the daya did not call for help. Spartan behaviour with sick infants is still the norm; children with congenital defects do not survive and a child born after eight months of pregnancy will be left to die because of the belief that such an infant cannot develop and live.

Women will lower their dresses to the abdomen for an examination since the breast is not considered an erogenous zone. This explains why mothers will nurse their babies wherever they happen to be. Prolonged breast feeding is considered a contraceptive measure but when the woman becomes pregnant again her milk is considered dangerous to the nursling. Sons are the treasure and when a woman is asked how many children she has, she will count the sons and only after coaxing will she add the daughters. If one wishes to tease and offend a male, he has only to be called $A b u$ Banat (father of daughters) because this is a disgrace to any man.

Children are not considered valuable until the age of twelve but the aged are highly honoured and respected. The old are revered but dying is not fought by all available means and the approach is stoic. The wealthy old sheikh who was hospitalised for a cerebral vascular attack was discharged after six weeks and at home developed a severe pneumonia and heart complications. He discussed the situation with the physician, asked how much time he had and decided to die at home. Don't you think it best? and Dr. Kaminsky was forced to agree in spite of his training.

Perhaps the most moving experience in observing life and death in the desert was the case of the three year old cyanotic dyspnoeic girl brought to the doctor by her father. The child had pneumonia as a complication of measles, and had already been ill for some days. Here in the middle of nowhere with no facilities or phone to call for a helicopter, Dr. Kaminsky and a colleague tried to intubate and resuscitate the child to no avail. In the setting sun in Dahab, Kaminsky carried the dead child to the father.
Everyone cried including the father. Shukran Hakim, (thank you, doctor) Allah gives and Allah takes (Kaminsky 1981).

\section{SANITARIANS}

The Ministry of Health is likely to encounter a certain measure of resistance to the diffusion of new attitudes regarding environmental sanitation (Shuval 1955). The author noted that although a relatively high percentage of men, young people, and persons with some formal education in Taibe wanted change, the power was in the hands of the elders who would not be prone to accept new ideas. Nevertheless, the Ministry of Health began its program helped by funds and advice from the United States of America Operations Mission to Israel (USOM).

\section{Sewage disposal}

In 1956 they began by building ten chemical toilets for families, chosen by lottery to prevent favoritism and some near the school. Pamphlets with instructions in Arabic were distributed and everyone waited for results. The toilets were not used and after a few months were destroyed. Asked why this happened. the chairman of the Taibe local council answered that in Tel Aviv toilets were used with water and that was what the people in Taibe wanted. When Dr. Lifshitz (1981) countered that bringing in a central water supply would cost much money, the councilman replied, Ask for the money and you will get it. True enough, in one year 95 percent of the homes had running water (Lifshitz 1981).

Indoor toilets were still a luxury for a number of years. The report of the sanitarians for the years 19581961 noted that newly built homes had sewage disposal units but these were not built according to regulations. There were large septic tanks but the rocky earth did not permit the waste water to seep through to the limestone level and the sanitarians feared there would be problems in the future. Most of the households used latrines built in the yard and during the 1950's 15 percent of the homes did not have toilets of any kind. The latter homes were so old they would have had to be destroyed in order to build proper installations. By 1966, however, 87 percent of houses in Taibe and 99 percent in Tira had indoor toilets. (Survey of Development of Health Services in Tira, Taibe, Kalansawa, 1958-1961, Jubran, Munir 1981)

\section{Food produce}

Other functions of the sanitarians included supervision of groceries, butcher shops, coffee houses, restaurants, bakeries and workshops. All were in a very depressed hygienic state. Little if any refrigeration existed, the butchers did their own slaughtering and the meat was hung in the open, exposed to the elements and the flies. There were two kinds of bakeries, one for baking and selling and the second for housewives who brought their pittot (flat bread) dough from home to be baked in the central bakery. The delicious lebena, a soft cheese soaked in olive oil, made of unpasteurised milk under most unhygienic conditions was sold by the women in the market. Advice and guidance were given by the sanitarians. Improvements were however slow, the inhabitants made no demands on the shopowners and proving in court that home made dairy products were being sold was difficult. (Survey of Development of Health Services in Tira, Taibe, Kalansawa 1958-1961)

\section{Environmental hygiene}

Cleanliness of the environment was not given a high priority. It was not a male role to care for the yard, and no one's responsibility to clean public places. Shuval (1955) wrote that because of differentiation of roles between the sexes and the higher status of the male, even the educated man would not think of teaching his wife the necessity of keeping clean surroundings. A public health nurse and a social worker tried to teach the women in a Galilean village to make compost heaps of the refuse to use as fertiliser instead of throwing garbage in the pathway. The project was a huge success for all but the sanitarian who was not invited to participate. In anger he went to the elders to complain and to his consternation was told to leave the nurse and social worker to their work cleaning yards was a woman's affair.

\section{Division of authority}

Factors that added to the sanitarian's frustrations, were and continue to be, the division of authority among numerous government departments which rarely co-ordinated functions. Meat, fish and poultry quality control at source was under the jurisdiction of the Ministry of Agriculture; building 
and zoning were in the hands of the Ministry of Interior, as well as the local authorities who were to carry out changes. As such, organizational co-ordination and co-operation of activities in the field are often problematic. Planning, supervision, and control over environmental issues were fragmented and hamper the efficient delivery of services (Tulchinsky 1979). The report was written for the entire state and applicable to the Arab villages.

\section{Malaria control}

Malaria control was one of the most successful projects. Begun by the British Army, and continued by the British Mandate and Jewish organisations, mosquito eradication was carried out intensively until interrupted by the War of Independence in 1948. At the beginning of 1948 the field staff consisted of twenty workers without transport; by the end of the year there were more workers and more transport, wrote Professor Grushka (1968). That there were more workers can be vouched for, but improvement in transportation was an optimistic appraisal in the early years of the state.

The anti-malaria unit had inspectors, drivers, and temporary workers who did the actual spraying. Specimens of larvae and adults of the anopheles were sent to Jerusalem for identification, and reports were sent also on antimalaria activities. Use of DDT began in 1945 on an experimental basis and by 1949 it was the spray of choice. An experienced worker could spray forty to fifty rooms with a surface of 2000 square meters daily. Workers also cleared vegetation, did small drainage work and larvaciding at the sources. Positive results of this difficult work were seen in the annual report of 1965 when one indigenous case was found - a rate of 0,004 new cases per 1000 population as compared to 1.60 new cases per

\section{REFERENCES}

Ben Assa. B I. (1974). The sick beduin. Ha Refuah. LXXXVII (2), V73-76 (Hebrew)

Blum. Hedy Frank (1981). Interview Nazareth. Dr Frank Blum was Regional Health Officer in the Northern District of Israel

Brachot, Daniel (1981). Interview. Tel Aviv. Dr Branchot was Regional Health Officer in the Central District of Israel.

Feldman. Rachel (1981). Interview. Tel Aviv. Mrs Feldman was Chief Public Health Nurse in the Cemiral District of Israel.

Gordon, Ruth (1981). Interview. Beersheba. Isracl. Mrs Gordon in the Chief Public Health Nurse in the Southern Region. Israel.

Grushka, Tehodore (1\%68) Editor. Health Serices in Israel Jerusalem. Ministry of Health.

Jubran. Zahi (1981). Interview. Nazareth. Israel. Mr Juran is a sanitory inspector in the Nazareth Health Department.
1000 population in 1948 (Grushka 1968).

\section{CONCLUSION}

This brief survey shows successes and failures, frustrations and joys of the dedicated people in their work with a population that had its own ideas on health and illness, and did not always take kindly to Western practices. Dr. Brachot (1981) felt that the health team did not know enough about the population and were not active enough in village life to bring about change. Others have said that the village population advanced fifty years in a period of twenty years.

Infant mortality has been lowered from 62,5 per 1000 live births in 1955 to 30,4 per 1000 live births in 1977, with the greatest decrease in the age group of one month to one year. This is still much higher than the infant mortality rate of 13,8 per 1000 live births in the Jewish population (Statistical Abstract 1977).

Several thoughts arise upon observing these rates. The majority of nurses in Arab villages are still practical nurses, who lack sufficient skills in health education, and some Beduin tribes do not have services in their immediate vicinity. The statistics for 1977 show high fertility rates $(7,21$ children per woman among Moslem women) and high infant mortality $(31,5$ per 1000 live births) (Tulchinsky 1979) - very likely the consequences of less than optimum care given in the home. Among the Arab Christian population the mortality rate dropped from 43,9 per 1000 in 1960 to 16,2 in 1977 , and among the Druze the rate was 34,5 in the same year (Tulchinsky 1979). Fertility rates for Christian Arab women in 1976 showed 3,32 births per woman, and 7,25 per Druze woman (Statistical Abstract 1977). Again there is a correlation between high fertility and high infant mortality.

Kaminsky, Rami (1981). Interview. Tel Aviv. Israel Dr. Kaminsky was physician in the Sinai Desert

Lifshitz. Israel (1981). Interview Tel Aviv. Israel. Dr. Lif. shitz was District Health Officer in Netanya and Regional Health Officer in the Central District of Israel.

Ministry of Healih Annual Reports for the Years 1948, 1953 Jerusalem. Ministry of Health (Hehrew).

Mizrachi. Aharon (1981). Interview. Haifa. Dr Mizrachi was District Heilth Officer in Acre. Israc

Munir. Samir (1981). Interview. Nazareth. Mr Munir is a sanitary inspector in the Nazareth Health Department. Isracl.

Oser. Shoshana (81) Interview Jerusalem. Miss Oscr was Chief Nurse in the District Health Office in Acre, and National Supervisor in Mental Health in Israel

Report on acrivities of the Tira Health Centre for the year 1966. Photostat (Hebrew)

Ron. Ruth (1981) Interview. Tel Aviv. Isracl. Miss Ron is Deputy Chief Nurse. Ministry of Health. Jerusalem and lecturer $\mathrm{Tel}$ Aviv University. Israe
Mortality due to infectious diseases has declined for the entire population, Arabs and Jews. Tuberculosis, malaria, trachoma and polio are almost non-existent. Morbidity from communicable diseases is manifested in dysenteries, hepatitis and food poisoning (Tulchinsky 1979).

Maternal mortality rates have gone down to 0,3 per 1000 live births in 1977, as most of the women (99 percent) deliver in hospital and legislation has enabled all parturient women to enjoy safe delivery and several days rest from their chores.

Life expectancy has risen for males to 68,5 years and to 71,3 for females, which is comparable to the rates of developed countries (Tulchinsky 1979). Rehabilitation services have improved throughout the country, as has care of the chronically ill.

Contact with the Jewish population and improved radio and television exposure have brought about other changes. The two Arab men who asked the public health nurse twenty years ago what she thought would be the village reaction if their wives would dress in western fashion and whether to teach them to read and write, did not long remain the exception. Young women now read and write, and even work outside the home. An Iraqi educated physician from the West Bank was speechless when the village nurse said to him that in Israel nurses do not make tea when ordered to do so. The tea-break is now a discussion period.

Aged persons do not have as much voice in decisions, and some are even being left alone in time of need. Stoicism and fatalism towards life and death exist and family honor is of utmost importance.

Positive and negative changes can be observed; the positive can even be measured and plans can be drawn up for the future.

Rosenfeld. Henry (1956) Tuivbe: an analysis of its pattern of authoring and an investigation of basic health cond rions and atmudes. United States Operations Mission to Israel. Mimeograph.

Shuval, Judith T. (1955) Atritudes and hehaviour concerning health and sanitution. Jerusalem. The Israel Institute of Applied Social Research

Sratistical Abstract of Israel (1975, 1979) Jerusalem. Central Bureau of Statistics.

Survey of Development of Health Services in Tira. Taibe und Kalansawa 1958-1961. Tira Heaith Center. Typewritten Repirt (Hehrew).

The United States of America Operations Mission in Israe (1956) Report by J.B Spielholz. Development of public health practice in Israel. Tel Aviv. (Photostat)

Torrok. Viola (1981) Interview. Beersheba. Dr Torok is Regional Health Officer in the Southern Region of Israel.

Tulchinsky. T.H. Sasson. G. (1979). Health in Israel 1948 1978. Draft for the Minisiry of Health for the State of Israel. 